\title{
Toward Brand Equity: The Effect of Brand Awareness, Perceived Quality, Brand Association, and Brand Loyalty in Boutique Bakery Company
}

\author{
Erna S. Imaningsih and Yuli Vega \\ Faculty of Economics and Business Faculty, Universitas Mercu Buana
}

ABSTRACT

This study aims to determine the effect of brand awareness, perceived quality, brand association, and brand loyalty to brand equity. The object of this research is BreadLife's consumers in South Jakarta. The type of research used is explanatory research with quantitative approach.

The data collection technique is done by non-probability sample technique, with sample selection using accidental sampling method. Samples are 230 respondents who are BreadLife consumers in South Jakarta. Data analysis used is descriptive analysis and Path analysis.

Data analysis was done by using Partial Lest Square analysis with SmartPLS 3.0 program. The results showed that: brand awareness variables negatively affect and not significant to brand equity variable; perceived quality variable has positive and insignificant effect on brand equity; brand association variable has a positive and significant impact on brand equity; brand loyalty variable has a positive and significant effect on the brand equity.

With it, BreadLife must continue to maintain the quality of its products and conduct promotions. Thus, consumers get to know their products and make customers loyal.

Keywords: Product Quality, Service Quality, Customer Satisfaction, Customer Loyalty.

DOI: $10.7176 / \mathrm{JMCR} / 67-06$

Publication date: April $30^{\text {th }} 2020$

\section{PRELIMINARY}

Research Background

In the era of globalization, business competition becomes very sharp both in domestic market (national) and in global market (international). Without exception, in our country the business world is also growing rapidly. The development of bakery business in Indonesia continues to grow both small, medium and large businesses, either in the form of industry and boutique bakery. In Indonesia the bread industry becomes one of the options for the development of a profitable culinary business.

The dynamism of the boutique bakery business in Indonesia is still wide open, making the entrepreneurs, companies and investors competing to compete only to gain a big advantage on the Indonesian market. Not only in terms of sales alone, entrepreneurs must also be able to introduce their products to grab the attention of the market. The increasing demand of the varied community is a factor supporting other boutique bakery entrepreneurs to present the uniqueness of the products they offer.

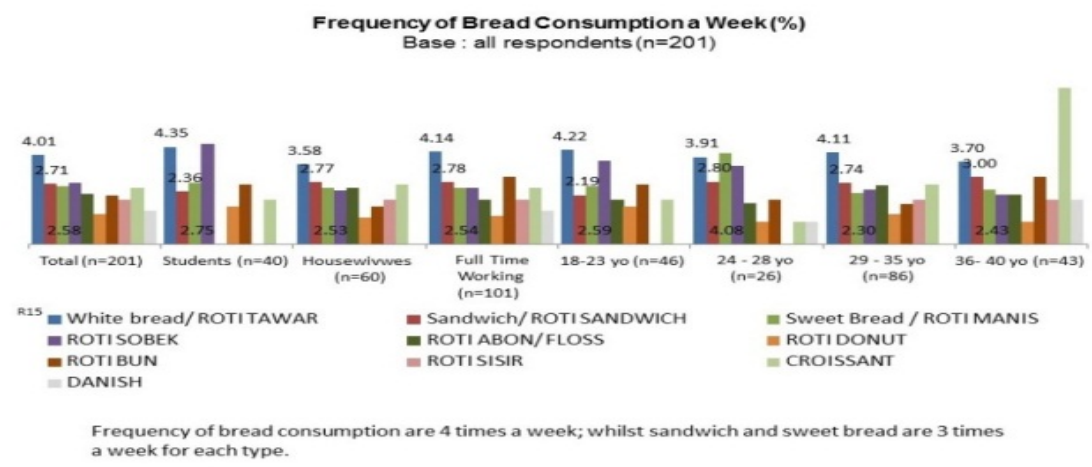

Figure 1 The Frequency of Bread Consumption Per Week

Source: Internal Company of a general nature

The number of bread types spread in Indonesia have different characteristics. Similarly, the fans, as shown by the data above that for the respondents at the age of 36-43 years, Croissant bread is very popular 
among them, while the type of bread bun and bread abon (floss) is a new entrant in the bakery business that is able to compete with others and be accepted in the community.

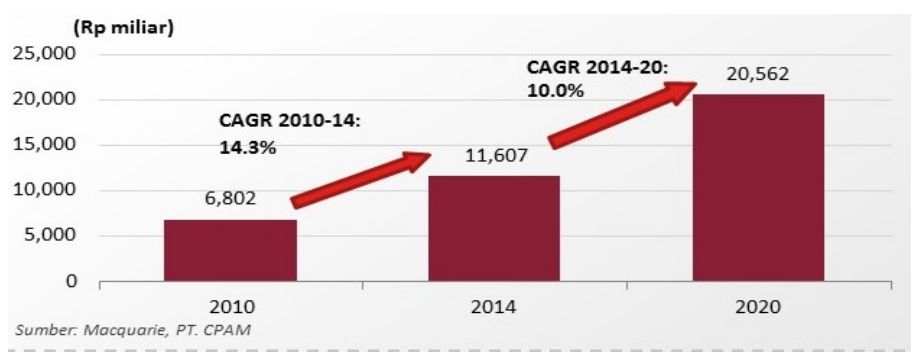

Figure 2 .Indonesian Bread Market

Source : PT CIMB Principal Aset Management (CPAM),2014

According to the data source above, it is shown that the growth of bread sales in Indonesia is estimated to reach 20\% CAGR in 2014-2020. If the increase in bread consumption will occur until the year 2020, it is undeniable that there will be more boutique bakery business growth or the same kind of business and more varied.

With the emergence of boutique bakery competition in Jakarta in attracting customers, a pretty interesting marketing strategy is needed. Many boutique bakery companies that appear like and others that have loyal customers because they have the character of the brand inherent in the consumer and the best product quality. The important of customer loyalty has been studied by Imaningsih, E.S, et al, 2019 with result that loyalty was influenced by branding strategy which is values orientation and satisfaction in green branding research.

From the above information and the phenomenon that occurs, the author is interested in doing research to find out the BreadLife brand equity after they do the revitalization. The study is titled "THE EFFECT OF BRAND AWARENESS, PERCEIVED QUALITY, BRAND ASSOCIATION, AND BRAND LOYALTY ON THE BRAND EQUITY IN BOUTIQUE BAKERY COMPANY (Case Study on BreadLife Boutique Bakery Consumers, PT Makmur Jaya World, South Jakarta).

\section{Formulation of The Research Problems}

Based on the phenomenon and the backgrounds, then the formulation of the problem of this study are as follows:

1. Does Brand Awareness affect Brand Equity on BreadLife's boutique bakery in South Jakarta?

2. Does Perceived Quality affect Brand Equity in BreadLife's boutique bakery in South Jakarta?

3. Does Brand Association affect Brand Equity in BreadLife's boutique bakery in South Jakarta?

4. Does Brand Awareness affect Brand Equity in BreadLife's boutique bakery in South Jakarta?

The Research Purposes

1. To analyze the influence of Brand Awareness to Brand Equity on Breadlife boutique bakery in South Jakarta?

2. To analyze the influence of Perceived Quality on Brand Equity in BreadLife boutique bakery in South Jakarta?

3. To analyze the influence of Brand Association on Brand Equity in BreadLife boutique bakery in South Jakarta?

4. To analyze the influence of Brand Loyalty on Brand Equity in BreadLife boutique bakery in South Jakarta?

\section{REVIEW OF LITERATURE, FRAMEWORK OF THINKING, AND HYPOTHESIS} Brand

Brand is "name, term, sign, symbol, or design, or combination used to identify goods or services of one seller or group of sellers and differentiate them from competitors" (Kotler and Keller, 2009). The role of brands in bringing the character of a product provides another dimension of imaging a product.

The brand definition by the American Marketing Association is a name, term, symbol, or design, or combination thereof intended to identify the seller's goods or services or group of sellers and to differentiate them from other products or services designed to satisfy the same needs (Kotler and Keller, 2009). 
Brand becomes very important for the company. Unnamed products will still serve as commodity, but on the contrary, product with brand will have a higher value in the eyes of the customer. Consumers view the brand as an important part of the product. Brand is the identity of a product.

Brand names help consumers recognize products that can benefit them. The brand also states something about the quality and consistency of the product. Buyers who always buy the same brand know that they will get the same features, benefits, and quality every time they buy. The role of brands in bringing the character of a product provides another dimension of imaging a product.

\section{Brand Equity}

Brand Equity according to Kotler and Keller (2009) is the added value given to product and services. Brand equity can be reflected in the way consumers think, feel and act in relation to brands, as well as price, market share, and profitability which is given by the brand for the company.

Brand Equity is the positive differential effect that if customers know the brand name, the customers will respond to the products and services (Kotler and Armstrong, 2008). Brand Equity is a kind of approach in marketing where the company considers that the brand is the most important asset that will greatly affect the profit. How big is the consumer's knowledge of the brand logo and other visual elements, and the perception of both the consumer and the continuity of the brand, depends on how strong the brand is.

According to Aaker (1991), Brand Equity is a set of associations and behaviors owned by brand customers, distribution channel members, and companies that enable a brand to gain strength, endurance, and excellence that can differentiate with a competitor's brand.

Based on the above definitions, it can be explained that brand equity is a series of assets and liabilities of the brand into consideration and memory in the minds of customers, so as to increase or reduce the value of a given product. Brand equity emerges due to differences in consumer responses. If there is no difference, then in essence the brand name product is a commodity or a generic version of the product.

\section{Brand Awareness}

Brand awareness is a measure of the strength of the brand's existence in the minds of customers. According to Aaker (1991), brand awareness is the ability of a potential buyer to recognize or recall that a brand is part of a particular brand category. A mechanism to expand the brand market by raising awareness. Then the awareness can affect consumer perception and behaviour. Thus, brand awareness is the awareness of consumers and potential consumers to be able to recognize or recall a brand with the difference to other similar brands.

\section{Perceived Quality}

According to Aaker (1991), perceived quality is customer perception of the overall quality or superiority of a product or service in relation to its intended purpose, compared to other alternatives. If the customer's perception of the overall quality is not good, no matter how much corporate effort to create loyalty to the product is unlikely to succeed. Moreover, Aaker (1991) state that the perception of quality is the perception of the customers for the attributes that are considered important to them.

According to Simamora in Aim Muzaqqi, Achmad Fauzi, and Imam Suyadi (2016) the impression of quality is the feeling of consumers on a brand or product and cannot be determined objectively. Whereas, according to Ferrinadewi (2008) perceived quality is how the overall superiority of the product is based on the subjective evaluation of the consumer. From some of the above definitions, it can be concluded that perceived quality is the customer's assessment of the overall product quality.

\section{Brand Association}

Aaker (2009) argues that brand association is anything directly or indirectly related in the customer's memory of the brand. The association inherent in the company and on its brand can be a major long-term business asset as it reflects the brand's strategic position.

According to Durianto, et al (2004), brand association is all the impression that comes to the mind of someone related to his memory of a brand.

\section{Brand Loyalty}

According to Aaker (1996), Brand Loyalty is a measure of proximity or customer relationship in a brand. Rangkuty (2008) also argues that brand loyalty is a measure of consumer loyalty to a brand. Brand loyalty is at the core of brand equity which is the central idea in marketing, as it is a measure of a customer's connection to a brand. If brand loyalty increases, the vulnerability of customer group from competitors' attacks can be reduced. This is an indicator of the brand equity associated with the acquisition of earnings in the future because of brand loyalty can directly be interpreted as a sale in the future. 


\section{The Relationship Between Variables and Hypotheses Development.}

\section{The Relationship between Brand Awareness to Brand Equity}

Raising awareness is a mechanism to expand the brand market. Awareness also affects perception and behavior. Brand awareness is the key of brand asset or key opening to enter into other elements. In the Chamid Abdul Basid, Leonardo Budi Hasiolan, Andi Tri Haryono Reasearch on "The Influence of Brand Image, Brand Attitudes and Brand Awareness of the Brand Equity of Frisian Flag Milk (Case Study in Tembalang Sub-district of Semarang") (2015) Brand awareness can affect brand equity through the creation of good brand credibility in the minds of customers. Brands with good credibility creates great confidence in the brand. Based on the theory, it can be concluded the hypothesis as follows:

H1: Brand awareness has a positive and significant impact on brand equity.

\section{The relationship between Perceived Quality and Brand Equity}

Lusi Sukiarti, Leonardo Budi H., and Andi Tri Haryono (2016) conducted a research on the Influence of Brand Image, Brand Attitudes, Brand Awareness and Brand Quality to Brand Equity of Hand \& Body Lotion Vaseline (Case Study in Pringapus Sub-district, Semarang). It is found that there is a positive and significant influence between brand attitudes and brand quality on brand equity.

Aaker (2009) also believes that the key to obtaining high quality perceptions is to provide high quality, identify key dimensions of quality, understand the signs of quality for consumers, and how to communicate quality messages in a convincing way.

The research was also conducted by Benny Sanjaya (2013), the study was on the Influence of Brand Awareness and Brand Association on Brand Loyalty through Perceived Quality in Nike Brand Shoes in Surabaya, the conclusion is that Brand Awareness, Brand Association has significant effect on Perceived Quality. The theory can be concluded as follows:

H2: Perceived quality has a significant and positive effect on brand equity.

\section{The Relationship between Brand Association on Brand Equity}

Product attributes and benefits to customers is an association that has real relevance as it provides reason to buy so that it becomes the basis for brand loyalty (Aaker, 2009). Research conducted by Aim Muzaqqi, Achmad Fauzi and Imam Suyadi in 2016 on the Influence of Brand Awareness, Quality Impressions, Brand Associations, and Brand Loyalty to Brand Equity (Survey on Consumer Buyers and Users of Apple Cider Products SIIPLAH in Saxophone Housing Kecamatan Lowokwaru Malang City) suggests that brand awareness, brand quality, brand association, and brand loyalty have a significant and positive impact on brand equity. Then it can be deduced that:

H3: brand association has a significant and positive impact on brand equity.

\section{Brand Loyalty Influence on Brand Equity}

Brand loyalty is one indicator of real brand equity and is linked to future earnings because it is directly linked to future sales levels. Loyal customers will generally continue to use the brand despite being faced with many alternative brands of competing products that offer superior product characteristics (Astini, Rina, 2016).

In a study conducted by Narulita Nora H. and Drs. H. Sutopo, MS. (2013) on the Analysis of the Influence of Brand Awareness, Quality Perceptions, and Brand Loyalty to Brand Equity, it is concluded that brand awareness does not have a strong (negative impact) effect on brand equity. The perception of Sunsilk brand quality does not have a strong influence on brand equity. Brand loyalty has a strong influence on brand equity

The opinion is also raised by research conducted by Muhammad, Imam Suyadi, Dahlan Fannani (2011) in his research on the Influence of Brand Awareness, Brand Association, Perceived Quality, and Brand Loyalty to Brand Equity (Survey on Consumers of Adolescent Age at Kelurahana Purwantoro Blimbing Malang Using IM3 Prepaid Card PT Indosat). With the results of his research proving that there is a significant influence of all variables brand awareness, brand association, perceived quality, and brand loyalty. So from the above theory can be concluded that:

$\mathrm{H} 4$ : brand loyalty has a positive and significant impact on brand equity.

\section{THEORETICAL FRAMEWORK}

The theoretical framework in this research can be seen in the picture below: 


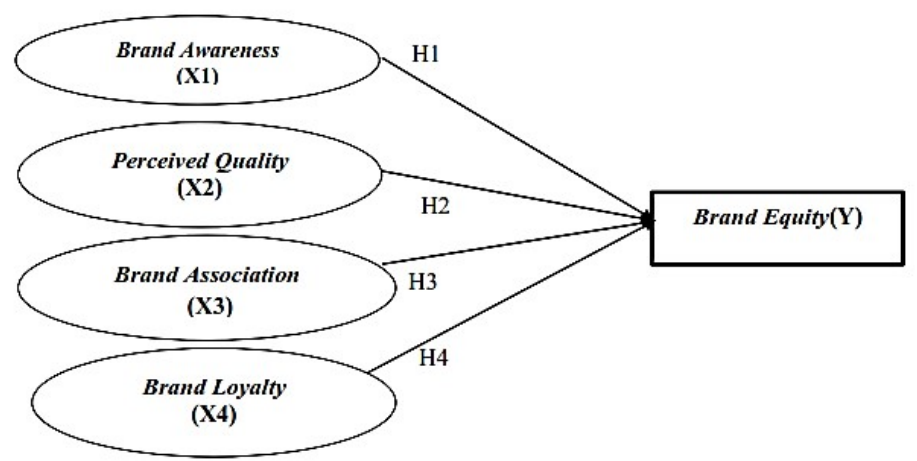

Figure 3. Research Hypothesis

\section{RESEARCH METHODOLOGY \\ Research Time and Place}

In the process of this study, certainly the researchers have determined the location where this research is done. The research will be conducted starting June 2017. The research will be conducted at BreadLife stores in South Jakarta in flexible time. The object of research in this research is BreadLife bread consumers who have consumed or have never consumed BreadLife bread.

\section{Research Design}

The type of research used by the researcher is causality research, that is research with the intention of measuring the strength of the relationship between two or more variables and showing the direction of relationship between the independent variable and the dependent variable, Kuncoro in Suharsono (2007).

The technique of collecting data used in this research is supported by primary data and secondary data. According to Istijanto (2009), primary data is the original data collected directly from the researcher to state the problem of his research specifically.

Data collection is done by distributing questionnaires to customers of BreadLife in South Jakarta. The research is conducted with quantitative descriptive approach and the type of research is case study supported by survey. The nature of this research is explanatory research (Explanatoring Research), a study that aims to describe and explain the nature of an ongoing situation at the time of the study conducted and examined the causes of the symptoms.

\section{Variable Measurement}

Variable measurement in the questionnaire uses Likert scale, namely by describing the variables that will be measured into a variable indicator. The answer has instrument from very positive to very negative.

With Likert scale, the variable to be measured is translated into indicator variable. Then the indicator is used as a starting point to arrange the items of the instrument that can be a statement or question (Sugiyono, 2012). The answer of each statement or question instrument using this Likert scale will produce a score as seen in the following instruments:
a. $\quad$ Strongly Agree $=$ Score 5
b. Agree $=$ Score 4
c. Simply Agree $=$ Score 3
d. Disagree $=$ Score 2
e. $\quad$ Strongly Disagree $=$ Score 1

\section{Research Population and Sample 1. Research Population}

Population is a composite of all elements in the form of events, things or people who have similar characteristics will become the center of a researcher's attention because it is viewed as a universe of research (Ferdinand, 2014). So it also can be said that population is the whole subject of research. Population in this research is the consumers of BreadLife outlets in South Jakarta. 


\section{Research Sample}

Determination of the minimum sample amount according to Hair et al (Ferdinand, 2014) is dependent on the number of indicators multiplied by five to ten. The appropriate sample size is between 100-200 samples. The determination of the number of representative samples depends on the number of indicators multiplied by 5 to 10 (Ferdinand, 2014) so that the number of representative samples in this study are: $46 \times 5=460$

\section{Partial Least Square (Smart-PLS Versi 3.0)}

Partial Least Square (PLS) analysis is an alternative to Ordinary Least Square (OLS) regression, canonical correlation or covariance based structural equation model (SEM) of independent variable system and response (Garson, 2016). In fact, PLS is sometimes called "SEM-based composite", "SEM-based components", or "SEM-based variants", in contrast to "SEM-based covariance" which is the usual type (eg, implemented by Amos, SAS, Stata, Mplus, LISREL, EQS and other major software packages).

In the response side, PLS can connect sets of independent variables to some dependent (response) variables. On the predictor side, PLS can handle many independent variables, even when the predictor displays multicolinearity. PLS can be implemented as a regression model, predicting one or more dependents from a set of one or more independent or can be implemented as a path model, handling predictive causal paths as well as predictor- related pathways with variable responses. PLS is implemented as a regression model with SPSS and by SAS PROC PLS. Smart PLS is the most common implementation as a road model.

\section{RESULTS AND DISCUSSION}

\section{Measurement Model Evaluation (outer Model)}

The outer model analysis is performed to ensure that the measurements used are appropriate for measurement (valid and reliable). The Outer Model is a measurement model consisting of indicators and pathways that connect them to their respective factors. Both weights and loads are outputs for both reflective and formative models (Garson, 2016). Analysis of model outer can be seen from some of the following indicators:

\section{Validity Test}

\section{Convergent Validity}

Convergent validity of the measurement model with reflective indicator model is judged by correlation between item score/component score with construct score calculated by PLS. Individual indicator is considered valid if it has correlation value above 0.70 . However, in the stage of scale development research, the loading factor of 0.50 to 0.60 is still acceptable (Chin, 1998 in Ghozali, 2012). By looking at the results of the correlation output between indicator with its construction as shown in the following structural drawing:

Table 4.4.

Convergent Validity Test

Source: Primary Data Processed by the Author (2017)

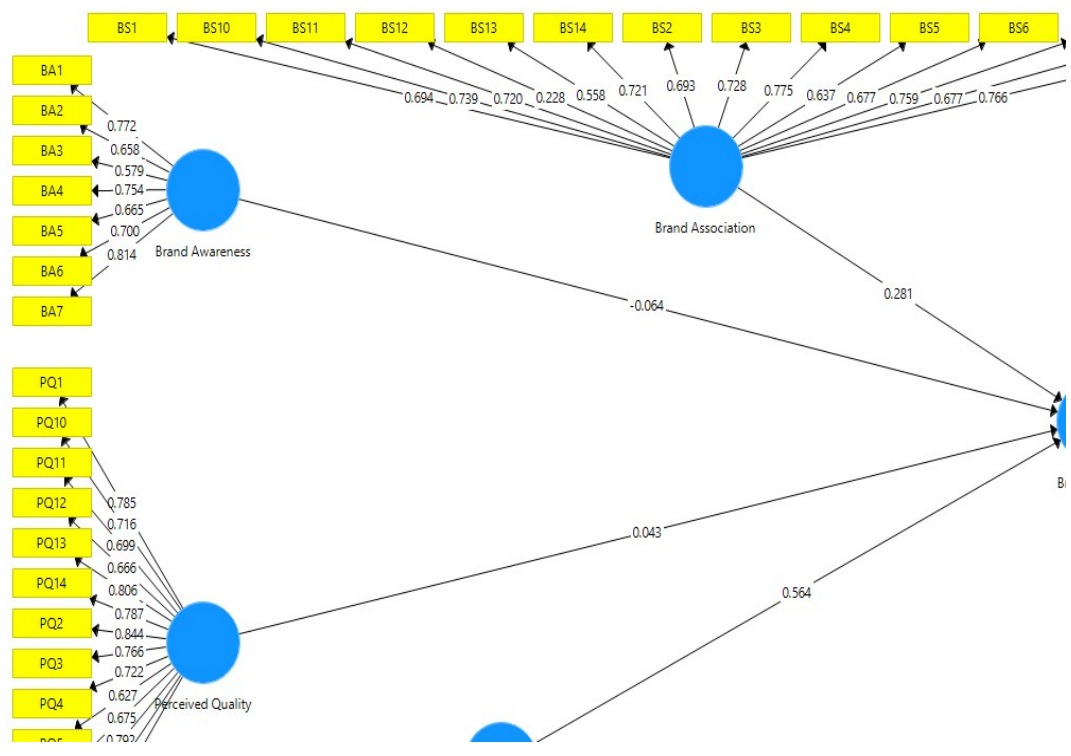


In Figure 4.4 above, it can be seen that in the structural model where the value of outer model or correlation between constructs with variables there still exist ones that have not fulfilled the convergent validity. The Factor loading value above indicator is still below 0.50 . To obtain a balanced result, then modification to the value of the factor loading indicator is done and the result can be seen as shown in Figure 4.5 on the following page.

\section{Table 4.5}

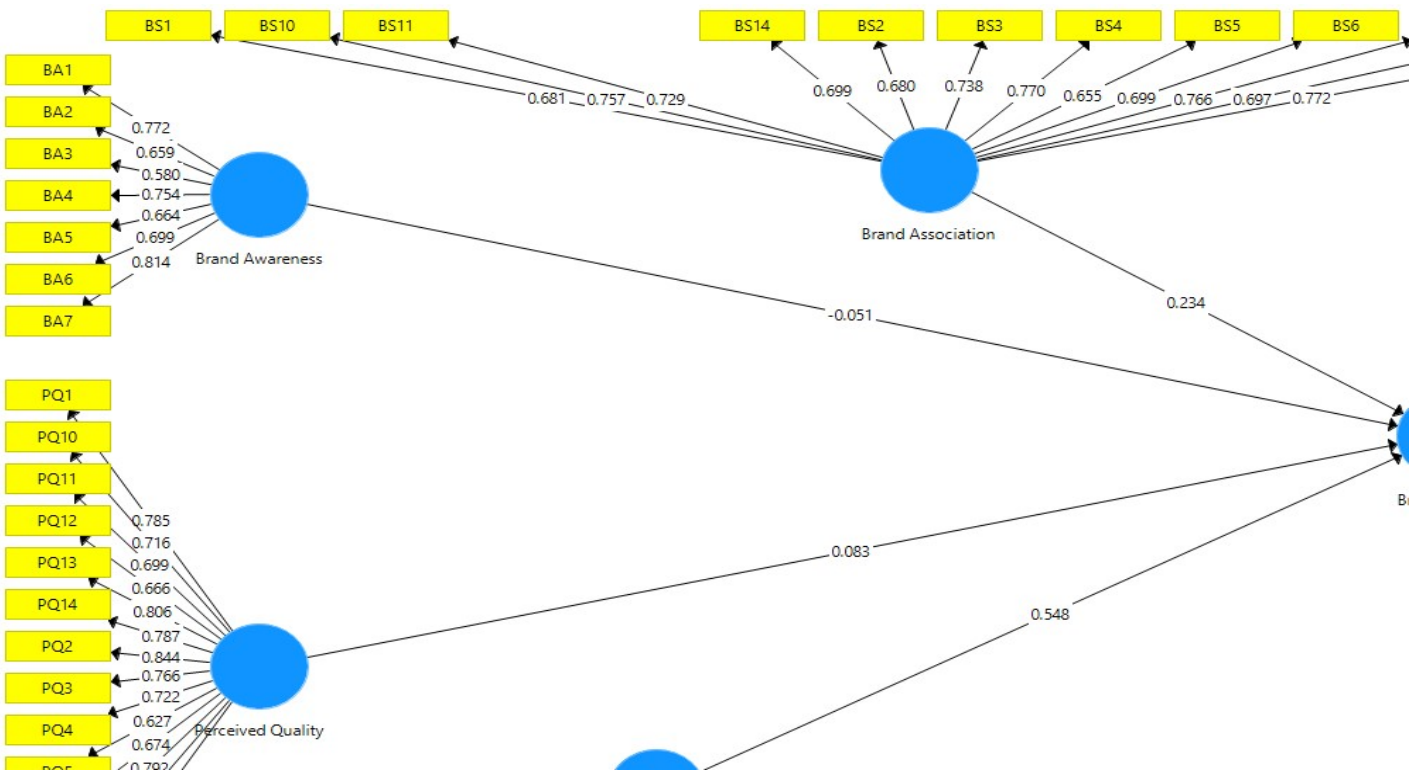

The Results of Modification Convergent Validty Test

Source: Primary Data Processed by the Author (2017)

Figure 4.5 is a structural model that is the result of data processed using SmartPLS 3.0. It can be seen in the structural model where the value of outer model or correlation between constructs with variables already meet the convergent validity where all indicators have a value factor loading more or less than 0.50 . At the modification stage, to meet its corresponding confergent validity then several indicators have been deleted in order to meet the Average Variance Extracted (AVE) value of not less or more than 0.50 . Here are the indicators that have been deleted:

On the previous page, it shows that the loading value of each indicator item to its construct is greater than its cross loading value. From the analysis of cross loading, it appears that there is no problem on discriminant validity.

Another method to see discriminant validity is to compare the square root of average variance extracted (AVE) value of each construct with the correlation between the other constructs in the model, then it is said to have a good discriminant validity value.

The Result of Discriminant Validity Test (Fornell Larcker Criterion)

\begin{tabular}{|c||c||c||c||c||c||}
\hline Variables & $\begin{array}{c}\text { Brand } \\
\text { Association }\end{array}$ & $\begin{array}{c}\text { Brand } \\
\text { Awareness }\end{array}$ & $\begin{array}{c}\text { Brand } \\
\text { Equity }\end{array}$ & $\begin{array}{c}\text { Brand } \\
\text { Loyalty }\end{array}$ & $\begin{array}{c}\text { Perceived } \\
\text { Quality }\end{array}$ \\
\hline \hline $\begin{array}{c}\text { Brand } \\
\text { Association }\end{array}$ & 0.721 & & & & \\
\hline \hline $\begin{array}{c}\text { Brand } \\
\text { Awareness }\end{array}$ & 0.546 & 0.71 & & & \\
\hline \hline Brand Equity & 0.674 & 0.387 & 0.853 & & \\
\hline \hline $\begin{array}{c}\text { Brand } \\
\text { Loyalty }\end{array}$ & 0.737 & 0.492 & 0.758 & 0.816 & \\
\hline \hline $\begin{array}{c}\text { Perceived } \\
\text { Quality }\end{array}$ & 0.774 & 0.498 & 0.641 & 0.751 & 0.757 \\
\hline \hline
\end{tabular}

Source: Primary Data Processed by the Author (2017) 
From the table shows that the square root of average variance extracted ( $\sqrt{\text { AVE}}$ ) is $0.721,0.71,0.853$, 0.816 and 0.757 . These values are greater than the correlation of each construct. Based on the square root of average variance extracted ( $\sqrt{\mathrm{AVE}}$ ) value above, then the constructs in the estimated model meet the discriminant validity criteria.

\section{Reliability Test}

The results of Composite Reliability and Cronbach's Alpha Test

\begin{tabular}{|c||c||c||c||}
\hline Variables & $\begin{array}{c}\text { Cronbach's } \\
\text { Alpha }\end{array}$ & $\begin{array}{c}\text { Composite } \\
\text { Reliability }\end{array}$ & Result \\
\hline \hline $\begin{array}{c}\text { Brand } \\
\text { Association }\end{array}$ & 0.916 & 0.928 & Realible \\
\hline \hline $\begin{array}{c}\text { Brand } \\
\text { Awareness }\end{array}$ & 0.84 & 0.876 & Realible \\
\hline \hline $\begin{array}{c}\text { Brand } \\
\text { Equity }\end{array}$ & 0.873 & 0.914 & Realible \\
\hline \hline $\begin{array}{c}\text { Brand } \\
\text { Loyalty }\end{array}$ & 0.899 & 0.922 & Realible \\
\hline \hline $\begin{array}{c}\text { Perceived } \\
\text { Quality }\end{array}$ & 0.931 & 0.941 & Realible \\
\hline
\end{tabular}

Source: Primary Data Processed by the Author (2017)

Based on the results of Composite Reliability testing, it shows a satisfactory value, because all values of latent variables have a value of Composite Reliability $\geq 0.7$. And the test results of Cronbachs Alpha also shows a satisfactory value, because all values of latent variables have a value of Cronbachs Alpha $\geq 0.7$.

\section{Structual Model Evaluation (Inner Model)}

Test Evaluation Hypothesis

The significance of estimated parameters provides useful information on the relationship between research variables. The basis used in testing the hypothesis is the value contained in the output of the result forinner weight. This test is done with the basis of data processing that has been done by using PLS program (Partial Least Square). The results of this test will show whether all the paths analyzed show significant results seen from the Original Sample and the $t$-statistic. To test the proposed hypothesis, we can see the value of $t$-statistics. The limit to reject and accept the proposed hypothesis is \pm 1.96 , whereby if the value $t$ falls within the range of values -1.96 and 1.96 then the hypothesis will be rejected or in other words accept the null hypothesis (H0). The result of the $t$-statistical estimation can be seen in the path coefficient (t-statistics)

\begin{tabular}{|l|l|l|l|l|}
\hline Description & Hypothesis & $\begin{array}{l}\text { Path } \\
\text { coefficient }\end{array}$ & value & Result \\
\hline Brand awarenes $\rightarrow$ Brand equity & H1 & 0,055 & 0,939 & Not supported \\
Perceived quality $\rightarrow$ Brand equity & $H 2$ & 0,062 & 0,522 & Not supported \\
Brand Loyalty $\rightarrow$ Brand equity & H3 & 0,247 & 2,673 & Supported \\
\hline
\end{tabular}




\section{Bootstrapping Test Results}

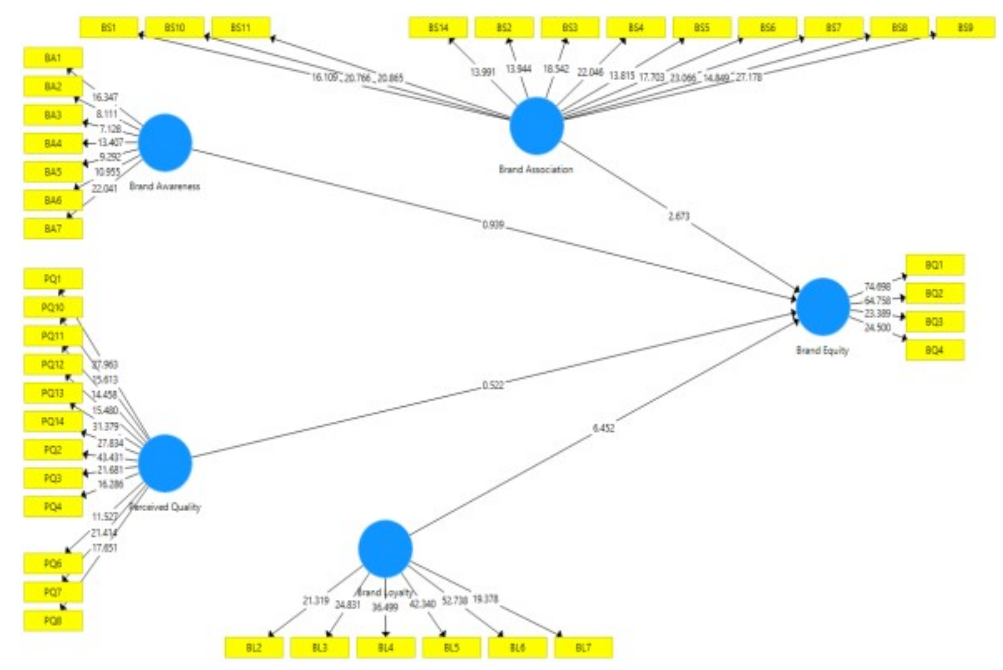

Source: Primary Data Processed by the Author (2017)

shows that the original sample value is -0.05 which indicates that the relationship between brand awareness to brand equity is negative. Then the value of $t$-statistic of $0.939(>1.96)$ means that the relationship between brand awareness to brand equity is not significant. So from the hypothesis H1 in this research, can be concluded that brand awareness have negative and insignificant effect to brand equity above show that relationship between perceived quality to brand equity is positive, it can be seen at original sample value that is 0,055 . While the $t$ statistic value of $0.522(>1.96)$ shows that the relationship between perceived quality of brand equity is not significant. So from the hypothesis $\mathrm{H} 2$ in this research, it can be concluded that perceived quality have positive but not significant to brand equity.

\section{Discussion of Research Results}

Based on the results of analysis PLS (Partial Least Square), then this section will discuss the results of calculations that have been done. This study aims to determine the effect of brand awareness, perceived quality, brand association, and brand loyalty to brand equity. Testing is shown through the existing hypothesis so it is known how the influence of each variable against other variables.

\section{Relationship between Brand Awareness and Brand Equity}

The first hypothesis (H1) states that there is a negative and insignificant influence between brand awareness on brand equity. The result of the calculation between brand awareness and brand equity shows there is negative influence of -0.05 with t-statistic value of $0.939(>1,96)$ and significance level of 0.348 indicating that the relationship between brand awareness (X1) to brand equity (Y) is negative and not significant.

The result of this hypothesis research is same as the result of research conducted by Lusi Sukiarti, Leonardo Budi H., and Andi Tri Haryono (2016). The results suggest that brand awareness does not have a strong (negative impact) effect on brand equity. However, this research is not in accordance with previous research done also by Chamid Abdul Basid, Leonardo Budi Hasiolan, Andi Tri Haryono (2015) who stated that brand awareness has a positive and significant influence on brand equity.

\section{Relationship between Perceived Quality and Brand Equity}

The second hypothesis (H2) states that there is a positive but not significant influence between pereived quality relationship to brand equity. The result of the calculation between perceived quality to brand equity shows a positive influence $(0.055)$, with $t$-statistic value of $0.522(>1,96)$ and the significance level of 0.602 which shows that it is not significant because the t-statistic value is below the critical point. This proves that the relationship between perceived quality (X2) to brand equity (Y) has no strong effect.

This research is similar to the research ever conducted by Narulita Nora H. and Drs. H. Sutopo, MS. (2013) where the results of his research states that perceived quality does not have a strong influence on brand equity. It is also different from the results of research conducted by Lusi Sukiarti, Leonardo Budi H., and Andi Tri Haryono (2016) stating that Perceived Quality has positive and significant influence on Brand Equity. 


\section{Relationship between Brand Association and Brand Equity}

The third hypothesis (H3) states that there is a positive and significant influence between Brand Association on Brand Equity. The result of brand association and brand equity calculation is positive (0.247) with $t$-statistic value of $2,673(>1.96)$ and significance level of 0.008 . The results of this research are in line with the research conducted by Imim Muzaqqi, Achmad Fauzi, and Imam Suyadi in 2016 whose research shows that Brand Association (X3) has a positive and significant influence on brand equity (Y).

\section{Relationship between Brand Loyalty and Brand Equity}

The fourth hypothesis (H4) states that there is a positive and significant influence between brand loyalty. The result of the calculation between brand loyalty and brand equity shows positive result (0.559) with $t$ statistic value of $6,452(>1,96)$ and level of significance 0 which shows the significance of brand loyalty relationship to brand equity. The results of this study indicate that it is brand loyalty that gives the greatest influence on brand equity. Then it can be concluded that brand loyalty (X4) has a positive and significant influence on brand equity (Y).

This research is in line with previous research conducted by Narulita Nora H. and Drs. H. Sutopo, MS. (2013) where brand loyalty has a strong influence on brand equity. The same opinion is also raised by the research conducted by Muhammad, Imam Suyadi, Dahlan Fannani (2011) with the results of his research proving that there is the same significant influence among brand awareness, brand association, perceived quality, and brand loyalty variables to brand equity.

\section{CONCLUSION AND SUGGESTION}

Conclusion

Based on the results of the analysis done, the conclusions obtained in this study are as follows:

1. Brand Awareness does not affect Brand Equity. Thus it can be concluded that even though consumers know the BreadLife bread brand, it does not guarantee that consumers be loyal.

2. Perceived Quality does not have a strong influence on Branding Equity. So it can be concluded that consumers have the perception of quality more or less the same in buying BreadLife bread with other bread brands.

3. Brand Association affects Brand Equity. Thus it can be concluded that the better the BreadLife brand association, the better the brand equity.

4. Brand Loyalty affects Brand Equity. Thus it can be concluded that the more loyal consumers the brand equity will increase.

\section{Suggestion}

Based on the results of the research, discussion and conclusion, the researchers can provide suggestions or input to the company and the next researchers, they are:

1. Practice

a) Is the efforts that can be used to enhance the ability of consumers to recognize the BreadLife product variant in order to increase brand awareness that is by increasing the frequency of advertisement serving that shows the BreadLife product variant. To support the advertising media, the company can also utilize Media Event Marketing (EM) and Marketing Public Relation (MPR) which is expected to be one effective step by looking at the progress of technological development now.

b) BreadLife should be able to highlight the characteristics of the brand so that consumers can be more familiar with the brand and it can be remembered in the minds of consumers spontaneously. The BreadLife philosophy based on Japanese culture can also be further highlighted through logos, packaging, staff uniforms, and others. So consumers can distinguish brands and characteristics with the characteristics of boutique bread that has the same concept.

c) Conducting a survey in the form of a questionnaire to consumers who have ever bought BreadLife bread which aims to improve the quality of the product so that consumers will feel getting attention and heard their needs. So in the end consumers will not move to other bread brand in the future because they have been satisfied with the quality improvement in accordance with the wishes of consumers.

d) Increasing price promotions for BreadLife bread variants so that consumers can become interested in buying BreadLife bread that can support brand loyalty to brand equity.

e) Maintaining the quality of bread to avoid defects or charred by improving bread maker skills to be more reliable and standardized so as to produce good bread. The use of quality materials can also be 
maintained so that BreadLife bread quality is not inferior to other products. If the consistency of bread quality can be maintained, then consumers will continue to buy bread in BreadLife. Quality maintained 2. Theory can support the brand's equity.

In this study, it is known that R-Square (R2) or coefficient of determination is $0.606(60.6 \%)$. This means that variations or changes in brand equity are influenced by brand awareness, perceived quality, brand association, and brand loyalty. While the rest of $39.4 \%$ is caused by other things.

With that, the researcher hopes that the next research can use other variables with the more relevant indicators so that it can explain the other causes that can influence relationship to brand equity. The development of such variables needs to be done in order to achieve better research results.

\section{REFERENCES}

Aaker, D. A. (1991). Managing brand equity. New York: Free Press.

Aaker, D. A. (1996). Building strong brands. New York: Free Press.

Aaker, David. (2009). Manajemen Ekuitas Merek.Jakarta : Spektrum.

Astini, Rina, 2016, Implikasi Green Brand Image, Green Satisfaction, dan Green Trust on Consumer Loyalty, Jurnal Manajemen/Volume XX, No. 01, Februari 2016: 19-34

Abdillah, Willy dan Jogiyanto Hartono. (2015). Alternatif Structural Equation Modeling (SEM) dalam Penelitian Bisnis. Yogyakarta: Andi Offset.

Astuti, Sri Wahyuni dan Cahyadi I Gde. (2007, Agustus 17). Pengaruh Elemen Ekuitas Merek Terhadap Rasa Percaya Diri Pelanggan di Surabaya Atas Keputusan Pembelian Kartu Perdana IM3. Majalah Ekonomi, 2.

Durianto, Darmadi, Sugiarto, L. J. Budiman. (2004). Brand Equity Ten Strategi Memimpin Pasar. Jakarta: PT.Gramedia Pustaka Utama.

Ferrinadewi, Erna. (2008). Merek dan Psikologi Konsumen, Implikasi pada Strategi Pemasaran. Yogyakarta: Graha Ilmu.

Garson, G David. (2016). Partial Leas Square: Regression \& Structural Equation Models. North Carolina: G. David Garson and Statistical Associates Publishing

Ghozali, Imam.(2014). Structual Equation Modeling - Metode Alternatif Dengan Partial Least Squares (PLS). Edisi 4. Semarang: Badan Penerbit Universitas Diponegoro.

Handayani, Desy \& dkk. (2010). The Official MIM Academy Coursebook Brand Operation. Esensi Erlangga Group. Jakarta.

Imaningsih, E.S, Tjiptoherijanto, Heruwasto, I, Aruan, DTH (2019), Linking of Egoistic, Altruistic, and Biospheric Values to Green Loyalty: The Role of Green Functional Benefit, Green Monetary Cost and Green Satisfaction, Journal of Asian Finance, Economics and Business Vol 6 No 2(2019), 277-286

Kotler, Philip dan Gay Armstrong. (2009). Prinsip-Prinsip Pemasaran. Edisi 12 Jilid 1. Jakarta: Penerbit Erlangga

Kotler, Philip dan Kevin Lane Keller. (2009). Manajemen Pemasaran. Edisi Ketiga Belas Jilid 1. Jakarta: Penerbit Erlangga.

Kotler, Philip. (2009). Manajemen Pemasaran. Edisi 13. Jakarta: Erlangga

Macquirie. (2015). Baking The Prosperity [PowerPoint slides]. Diunduh dari http://www.cimbprincipal.com/images/articles/indonesia/Weekly\%20Perspective/2015/March/2015\%200 3\%2018\%20CPAM $\% 20$ Weekly $\% 20$ Indo $\% 20$ Perspective $\% 20-\% 20$ Baking $\% 20$ the $\% 20$ Prosperity.pdf

Rangkuti, Freddy. (2008). The Power of Brands. Jakarta: Gramedia Pustaka Utama

Sugiyono. (2010). Metode Penelitian Bisnis. Edisi III. Bandung: Alfabeta.

Sugiyono. (2010). Metode Penelitian Pendidikan Pendekatan Kuantitatif, kualitatif, dan R\&D. Bandung: Alfabeta

Surachman. (2008). Dasar-dasar Manajemen Merek 9Alat Pemasaran Untuk Memenangkan Persaingan). Malang: Bayu Media Publishing.

Sugiyono. (2013). Metode Penelitian Manajemen. Bandung: Alfabeta

Tjiptono, Fandy. (2008). Strategi Pemasaran. Edisi 3. Yogyakarta: Andi Offset

Tjiptono, Fandy. (2014). Pemasaran Jasa. Yogyakarta: Andi Offset

Adiputra, Danang. (2011). Analisis Kesadaran Merek, Persepsi Kualitas, Asosiasi Merek, dan Loyalitas Merek yang mempengaruhi Ekuitas Merek Produk Sepatu Olahraga Merek ADIDAS (Studi Kasus Pada Masyarakat di Kota Semarang). 
Basid,Chamid Abdul, Leonardo Budi Hasiolan, dan Andi Tri Haryono. (2015). Pengaruh Citra Merek, Sikap Merek dan Kesadaran Merek terhadap Ekuitas Merek Susu Frisian Flag (Studi Kasus di Kecamatan Tembalang Semarang).

Muhammad, Imam Suyadi, dan Dahlan Fannani. Pengaruh Brand Awareness, Brand Association, Perceived Quality dan Brand Loyaalty Terhadap Brand Equity (Survei Pada Konsumen Usia Remaja Di Kelurahan Purwantoro Kecamatan Blimbing Malang Yang Menggunakan Kartu Prabayar IM3 PT.Indosat). Jurnal Administrasi Bisnis (JAB). Vol. 7, No. 2. Januari 2014.

Muzaqqi, Aim, Achmad Fauzi, dan Imam Suyadi. Pengaruh Kesadaran Merek, Kesan Kualitas, Asosiasi Merek dan Loyalitas Merek Terhadap Ekuitas Merek (Survei pada Konsumen Pembeli dan Pengguna Produk Sari Apel SIIPLAH di Perumahan Saxophone Kecamatan Lowokwaru Kota Malang). Jurnal Administrasi Bisnis (JAB). Vol. 31, No. 1. Februari 2016.

Nora, Narulita H., dan H. Sutopo (2011). Analisis Pengaruh Kesadaran Merek, Persepsi Kualitas, dan Loyalitas Merek Terhadap Ekuitas Merek ( Studi Kasus Pada Pengguna Shampoo dan Kondisioner SUNSILK Kota Semarang)

Rios, Rosa E., Hernan E. Riquelme. (2008).Brand equity for online companies.Marketing Inteligence and Planning Vol. 26, No. 7, 2008.

Sasmita, Jumiati dan Norazah Mohd. Suki.2014). Young consumers' insights on brand equity Effects of brand association, brand loyalty, brand awareness, and brand image. International Jurnal of Retail \& Distribution Management Vol.43 No. 3, 2015.

Sukiarti, Lusi, Leonardo Budi H., dan Andi Tri Haryono. (2016). Pengaruh Citra Merek, Sikap Merek, Kesadaran Merek dan Kualitas Merek Terhadap Ekuitas Merek, Hand \& Body Lotion Vaseline (Studi Kasus di Kecamatan Pringapus, Kabupaten Semarang ). Journal Of Management, Volume 2 No. 2 Maret.

Sundjoto, dan Agus Safan Hadi. (2012). Pengaruh Citra Merek dan Kesadaran Merek Terhadap Ekuitas Merek Susu Cair dalam Kemasan "Frisian Flag". Jurnal Media Mahardhika Vol. 11 No 1 September 2012.

Sanjaya, Benny. (2013). Pengaruh Brand Awareness dan Brand Association Terhadap Brand Loyalty Melalui Perceived Quality Pada Sepatu Merek NIKE di Surabaya.

http://www.topbrand-award.com/

http://breadlifebakery.com/ 